\title{
MENGUJI KESIAPAN PENGELOLAAN DESA WISATA BERBASIS MANAJEMEN MODERN SEBAGAI PENGGERAK EKONOMI RAKYAT
}

\author{
N. M. Puriati ${ }^{1}$, G. S. Darma ${ }^{2}$ \\ 1,2 Magister Manajemen, Pendidikan Nasional University, Denpasar \\ email: puriati88@gmail.com, sridarma@undiknas.ac.id
}

\begin{abstract}
Abstrak
Tujuan dari penelitian ini adalah mengetahui cara menguji kesiapan pengelolaan Desa Wisata Sanur Kaja, berbasis manajemen modern, dan mengetahui faktor-faktor yang mempengaruhi suatu desa dikatakan telah siap diterapkannya manajemen modern. Penelitian ini menggunakan pendekatan kualitatif field research method. Hasil dari penelitian ini diperoleh bahwa pelaksanaan manajemen modern yang dilakukan oleh Desa Sanur Kaja sebagai desa wisata adalah dengan dimanfaatkannya teknologi informasi dalam melakukan aktivitas pariwisata. Pemanfaatan media teknologi informasi seperti internet dalam upaya mendukung desa wisata adalah pemanfaatan internet sebagai media promosi. Selain pengelola wisata, pelaku-pelaku wisata yang ada di Desa Sanur Kaja juga telah memanfaatkan internet sebagai media promosi. Strategi pemasaran menggunakan ecommerce membantu memberikan masukan sebagai bahan pertimbangan dalam pengembangan strategi digital marketing baik menggunakan website dan media sosial maupun online marketing mix. Saran bagi pelaku pariwisata, terutama pelaku usaha kecil yang ada di Desa Sanur Kaja perlu melakukan pelatihan mengenai e-commerce sebagai sarana promosi.
\end{abstract}

Kata kunci: desa wisata, manajemen modern, strategi pemasaran

\begin{abstract}
The purpose of this research is to find out how to test the readiness of the management of Sanur Kaja Tourism Village, based on modern management, and to know the factors that influence a village which is said to be ready to implement modern management. This study used a qualitative field research method approach. The results of this study indicate that the implementation of modern management carried out by Sanur Kaja Village as a tourist village is by utilizing information technology in carrying out tourism activities. The use of information technology media such as the internet in an effort to support tourism villages is the use of the internet as a promotional medium. Apart from tourism managers, tourism actors in Sanur Kaja Village have also used the internet as a promotional medium. A marketing strategy using e-commerce helps provide input as material for consideration in developing a digital marketing strategy using both websites and social media as well as the online marketing mix. Suggestions for tourism actors, especially small business actors in Sanur Kaja Village, need to conduct training on e-commerce as a means of promotion.
\end{abstract}

Keywords: marketing strategy, modern management, tourism village

\section{Pendahuluan}

Seiring dengan pesatnya perkembangan industri pariwisata dewasa ini, diperlukan pembangunan infrastruktur yang dapat menunjang kemajuan pariwisata. Hal ini disebabkan karena sektor pariwisata sebagai salah satu sektor yang menunjang peningkatan pendapatan daerah. Pariwisata merupakan fenomena yang muncul karena adanya interaksi antara wisatawan, penyedia jasa/industri wisata, dan pemerintah dalam menyediakan fasilitas dan layanan yang mendukung kegiatan wisata. Berbagai interaksi tersebut membentuk suatu sistem yang saling terhubung satu dengan lainnya (Tyas \& Damayanti, 2018).

Dalam mewujudkan kemajuan negara, dibutuhkan upaya dalam memberdayakan masyarakat yang berbasis pada kekayaan sumber daya alam dan budaya yang dimiliki oleh 
lingkungan tempat masyarakat tinggal. Hal ini tentunya merupakan sebuah upaya agar masyarakat dapat memanfaatkan sumber daya yang ada secara optimal sehingga dapat tercapainya kemandirian, kemajuan dan kesejahteraan masyarakat. Berhasilnya proses penguatan kemandirian dalam mengelola sumber daya desa akan meningkatkan kemampuan masyarakat dalam mempertahankan kesejahteraan tanpa harus bergantung pada pihak lain (Nurazizah \& Darsiharjo, 2018). Berdasarkan penelitian dari Manteiro (2016) belum adanya pengembangan desa wisata berbasis kearifan lokal yang maksimal sebagai upaya pengentasan kemiskinan untuk mengatasi ketidakberdayaan masyarakat miskin yang disebabkan oleh keterbatasan akses, kurangnya pengetahuan dan keterampilan, terperangkap dalam kemiskinan (poverty trap) dan ketidakberdayaan masyarakat. Oleh sebab itu diperlukan pengembangan lebih lanjut untuk mewujudkan kemandirian masyarakat di 3 (tiga) hal tersebut, terutama meningkatkan keterlibatan dan peran serta secara aktif masyarakat pada berbagai kegiatan peningkatan pendapatan dan kesejahteraan serta adanya pemanfaatan desa wisata oleh masyarakat maupun pemerintah setempat.

Desa wisata adalah suatu bentuk integrasi antara atraksi, akomodasi dan fasilitas pendukung yang disajikan dalam suatu struktur kehidupan masyarakat yang menyatu dengan tata cara dan tradisi yang berlaku (Nuryanti, 1993). Desa wisata adalah komunitas atau masyarakat yang terdiri dari penduduk suatu wilayah terbatas yang dapat saling berinteraksi secara langsung di bawah sebuah pengelolaan dan memiliki kepedulian, serta kesadaran untuk berperan bersama sesuai keterampilan dan kemampuan masing-masing, memberdayakan potensi secara kondusif bagi tumbuh dan berkembangnya kepariwisataan di wilayahnya. Desa wisata menempatkan komunitas atau masyarakat sebagai subjek atau pelaku utama dalam pembangunan kepariwisataan, kemudian memanfaatkannya bagi kesejahteraan masyarakat. Dalam aktivitas sosialnya, kelompok swadaya dan swakarsa masyarakat berupaya untuk meningkatkan pemahaman kepariwisataan, mewadahi peran dan partisipasi masyarakat dalam pembangunan kepariwisataan di wilayahnya, meningkatkan nilai kepariwisataan serta memberdayakannya bagi kesejahteraan masyarakat. Sebagai pelaku utama, komunitas atau masyarakat berupaya meningkatkan potensi pariwisata atau daya tarik wisata yang ada di wilayahnya. Selanjutnya, komunitas atau masyarakat menyiapkan diri sebagai tuan rumah yang baik bagi para wisatawan ketika berkunjung. Seluruh kegiatan yang dilakukan oleh komunitas atau masyarakat di desa wisata, memiliki tujuan untuk meningkatkan kesejahteraan ekonomi masyarakat dengan mendayagunakan aset dan potensi yang dimiliki (Ensiklo, 2019)

Untuk menguji kesiapan suatu desa menjadi desa wisata, diperlukan beberapa aspek yang harus diperhatikan. Beberapa aspek tersebut apakah sudah dimiliki oleh suatu desa yang akan menjadi desa wisata. Beberapa aspek berikut ini sebagai langkah strategis dalam mengembangkan potensi desa menjadi desa wisata (Berdesa, 2015) yaitu: 1) Mengidentifikasi potensi desa dengan cara bermusyawarah dan berdiskusi bersama seluruh komponen desa dari semua kalangan, untuk membahas potensi desa yang dapat dibentuk menjadi komoditas yang dipandang dari segala aspek, dapat berupa keindahan alam, hasil bumi, kekayaan flora fauna/hayati, adat dan budaya / sosio kultural, masyarakat, tradisi atau hal-hal yang bersifat khas/unik yang tidak dimiliki pada daerah lain. Mengidentifikasi potensi unggulan yang dimiliki oleh desa agar dapat dijadikan komoditas utama. 2) Mengidentifikasi permasalahan yang menjadi penghambat dalam pengembangan potensi wisata desa, dari sudut pandang hal hal yang bersifat fisik, non fisik atau sosial, internal dan eksternal, atau dapat juga dari permasalahan yang ada, dipandang sebagai tantangan yang jika di olah dan dikembangkan dengan cara tertentu dapat menjadi potensi desa wisata. 3) Adanya komitmen yang kuat dari seluruh komponen desa untuk menyamakan pendapat, persepsi dan mengangkat potensi desa guna dijadikan desa wisata. Komitmen ini yang menjadi dukungan terkuat bagi terwujudnya dan keberlangsungan desa wisata. 4) Mengidentifikasi 
dampak yang terjadi bagi pengembangan desa wisata baik dampak positif maupun negatif dari sebuah kegiatan wisata, sesuai dengan keunikan masing-masing desa. Masing-masing desa memiliki karakteristik sendiri akan menghasilkan dampak yang berbeda satu sama lain terutama adanya perubahan adat dan budaya / sosial kultural. 5) Adanya komitmen yang kuat dari seluruh komponen desa untuk menggandeng Pemerintah Daerah dan jika perlu menggandeng pihak swasta. Hal yang perlu dilakukan juga adalah menganalisa dan mengidentifikasi dampak jika bekerja sama dengan pihak swasta, termasuk untuk penganggaran guna pembangunan desa wisata dengan menggunakan seluruh sumber daya ekonomi yang ada. 6) Desa memiliki kesiapan segala perangkat aturan / regulasi norma yang lebih bertujuan untuk mengawal pengembangan desa wisata dan mengawasi potensipotensi penyimpangan yang mungkin saja dapat terjadi. Regulasi disiapkan agar berjalannya aktivitas wisata beserta dampaknya tetap berada dalam koridor regulasi sebagai payung hukumnya. 7) Adanya pelatihan-pelatihan bagi seluruh komponen desa, termasuk pemerintah desa tentang manajemen pariwisata berbasis manajemen modern yang didukung dengan teknologi informasi di era teknologi 4.0, bagaimana mengelola tempat wisata, manajemen tamu/pengunjung, beserta inovasi-inovasi yang perlu dikembangkan dengan sentuhan teknologi yang dapat memberikan nilai lebih / addedvalue bagi desa wisata, untuk selalu berinovasi dan berkembang seiring berkembangnya teknologi yang selalu memberikan sesuatu yang baru bagi wisatawan nantinya. 8) Memanfaatkan media cetak, elektronik atau media sosial untuk memperkenalkan dan mempublikasikan potensi wisata di desa, seperti perkembangan teknologi saat ini yang sangat berkembang dengan memanfaatkan media internet. Internet kini menjadi sarana publikasi yang sangat efektif yang menjangkau tanpa batas jarak waktu dan tempat, destinasi wisata yang lokasinya terpencil pun dapat diketahui oleh masyarakat dunia. 9) Belajar pada kesuksesan desa wisata lain atau melakukan studi banding. Desa wisata dapat belajar banyak dari keberhasilan desa wisata lain khususnya yang sejenis, karena permasalahan dan tantangan masa depan yang bakal dihadapi, kurang lebih sama dan tidak banyak berbeda, hanya melalui manajemen profesional dan inovatif, desa wisata akan eksis dan kompetitif melalui ujian yang bersifat internal, eksternal maupun regional internasional.

Saat ini, keberadaan dan kemajuan pariwisata belum dapat dirasakan langsung dan belum dapat memberikan manfaat yang besar bagi masyarakat sekitarnya. Beberapa provinsi yang menjadi primadona pariwisata di Indonesia masih memiliki tingkat kemiskinan dan pariwisata belum berdampak signifikan bagi perekonomian desa tersebut. Hal ini disebabkan karena masyarakat masih belum mampu mengelola pariwisata sendiri dan walaupun beberapa kelompok masyarakat sudah mengelola pariwisata berbasis community based tourism tetapi masih menggunakan pola manajemen sederhana sehingga saat terjadinya krisis global seperti pandemi virus corona yang saat ini merebak maka sangat rentan terjadi resesi ekonomi. Dengan demikian diperlukan strategi manajemen kebijakan publik bidang sektor pariwisata yang dari pemerintahan daerah dan masyarakat, berupa perubahan pengelolaan menggunakan pola pengelolaan berbasis manajemen modern untuk memberikan dampak jangka panjang bagi peningkatan ekonomi bagi daerah wisata tersebut.

Manajemen modern adalah manajemen yang pada periodenya ditandai dengan sudah dipelajari manajemen sebagai ilmu yang mempunyai dasar-dasar logika ilmiah, sehingga banyak melibatkan ahli manajemen maupun ahli ekonomi untuk melakukan penelitian tentang manajemen yang menghasilkan berbagai teori maupun aliran manajemen. Teori-teori ini pertama kali dirintis Robert Owen, Adam Smith, Charles Babbage dan Max Weber. Terminologi modern, dalam The Contemporary English-Indonesia, diutarakan terbaru; modernism: sikap, pikiran, tingkah laku yang modern; modernisasi: pembaruan agar sesuai dengan zaman sekarang. Pengertian modern menunjukkan adanya penggantian atas sesuatu yang sebelumnya merupakan cara mengerjakan sesuatu yang sudah disepakati. 
Manajemen modern adalah manajemen dengan bertumpu pada seberapa landasan pemikiran, seperti: konsep sistem, analisis keputusan, pentingnya faktor manusia serta tanggung jawab sosial manusia dalam organisasi. Manajemen modern juga masih tetap bersumber pada pemikiran yang terbaik dari manajemen. Manajemen modern dibangun berlandaskan praktik-praktik terbaik manajemen, yang dibantu oleh pendekatanpendekatan, arahan, teknik dan sikap baru (Sedarmayanti, 2012).

Konsep pengembangan desa wisata mengacu pada keberadaan unsur $3 \mathrm{~A}$ dalam pariwisata dan community involvement atau keterlibatan masyarakat (Ensiklo, 2019). 3A yang dimaksud adalah atraksi, amenitas dan aksesibilitas. Atraksi, yaitu adanya atraksi sebagai daya tarik utama desa wisata, sedangkan amenitas sebagai fasilitas pendukung yang dimiliki oleh desa wisata dan aksesibilitas yang dapat diartikan sebagai beragam hal yang berkaitan dengan akses wisatawan ketika hendak berkunjung ke desa wisata. Unsur $3 \mathrm{~A}$ ini penting dimiliki oleh desa wisata, karena akan berpengaruh pada tingkat kunjungan wisatawan, lama tinggal wisatawan (length of stay) dan minat wisatawan untuk berkunjung kembali. Unsur-unsur dari desa wisata adalah memiliki potensi wisata, seni, dan budaya khas setempat, aksesibilitas dan infrastruktur mendukung program desa wisata, terjaminnya keamanan, ketertiban, dan kebersihan. Pijakan dasar dalam pengembangan desa wisata adalah pemahaman terhadap karakter dan kemampuan unsur-unsur yang ada dalam desa, antara lain: lingkungan alam, sosial ekonomi, budaya masyarakat, arsitektur, struktur tata ruang dan aspek historis, termasuk indigeneus knowledge (pengetahuan dan kemampuan lokal) yang dimiliki oleh masyarakat. Berdasarkan indikator yang disampaikan Nurhayati diatas merupakan faktor penting dalam membentuk atau membangun sebuah desa sebagai desa wisata.

Desa Wisata Sanur Kaja merupakan salah satu desa wisata yang terletak di Kecamatan Denpasar Selatan, Kota Madya Denpasar dengan potensi alam maupun budaya yang berpotensi untuk pengembangan pariwisata. Unsur unsur yang terdapat dalam desa wisata tersebut, Desa Wisata Sanur Kaja memiliki potensi besar sebagai desa wisata. Desa wisata berbasis masyarakat merupakan aktifitas ekonomi yang sangat penting jika dikembangkan dengan baik, maka dapat mengatasi sejumlah tantangan pembangunan seperti halnya kemiskinan. Selain ketersediaan sumber daya manusia, potensi wisata / sumber daya alam Desa Sanur Kaja memiliki SDA yang melimpah, yang lokasinya berada di Kecamatan Denpasar Selatan sangat strategis dalam membangun desa wisata yang berbasis lingkungan

Beberapa obyek wisata Desa Sanur Kaja diantaranya Pantai Matahari Terbit, Pantai Bali Beach, dan Pantai Segara Ayu sebagai obyek wisata yang terkenal akan pesona matahari terbitnya di pagi hari dan pasir putihnya. Selain itu terdapat Museum Le Mayuer yang berisi koleksi seni lukis peninggalan Le Mayeur seorang pelukis asal Belgia. Pada obyek wisata pantai matahari terbit sampai pantai mertasari terdapat area jogging track bagi wisatawan yang suka bersepeda atau sekedar jalan-jalan, di desa ini yang membentang di pinggir pantai dari pantai Matahari terbit sampai ke pantai Mertasari dengan panjangnya mencapai 5,8 km. Setiap tahun pada bulan Agustus terdapat event tahunan yang bernama Sanur Village Festival, dimana pada festival tersebut terdiri dari kegiatan bazaar, festival kuliner dan atraksi seni serta budaya. Potensi alam dan budaya yang sangat melimpah jika dikelola dengan baik akan berdampak bagi meningkatnya perekonomian mayarakat setempat. Namun pengelolaan yang dilakukan masih belum menunjukkan dampak yang maksimal bagi perekonomian masyarakat desa Sanur Kaja, berdasarkan pengamatan pengelolaan masih dilakukan secara semi-modern.

Berdasarkan permasalahan yang diuraikan diatas, penelitian ini meneliti Desa wisata di wilayah Sanur Kaja untuk mengetahui dan menguji kesiapan pengelolaan berbasis manajemen modern, yang berbasis teknologi 4.0 agar potensi desa dapat dikembangkan 
secara maksimal dan desa memiliki ketahanan ekonomi terutama saat terjadinya krisis sehingga meminimalisasi dampak krisis yang terjadi bagi desa dan masyarakat di desa tersebut.

\section{Metode}

Penelitian ini berlokasi di Desa Wisata Sanur Kaja, Kecamatan Denpasar Selatan, Bali. Alasan memilih lokasi ini karena Desa Wisata Sanur Kaja, sebagian besar merupakan daerah pemukiman dan kawasan pariwisata yang sudah terkenal bagi wisatawan domestik dan internasional serta perdagangan penunjang pariwisata. Dalam penulisan penelitian ini, menggunakan metode pengumpulan data, yaitu: Metode field research, metode pengumpulan data dengan mengadakan penelitian secara langsung kepada objek penelitian yang telah di tentukan. Dalam penelitian ini, wawancara dilakukan dengan dua tahapan. Berdasarkan hal tersebut informan dibagi menjadi dua tahapan, yakni tahap structured interview (wawancara berstruktur) dan semistructure interview (wawancara semistruktur). Dalam penelitian ini, pemilihan informan dilakukan dengan menggunakan teknik purposive sampling dengan jenis judgement sampling atau sampel bertujuan secara subjektif. Dalam penelitian ini, informan diuraikan sebagai berikut: Informan dalam tahap wawancara SemiTerstruktur atau semi-structured interview, informan dalam tahap ini adalah Kepala Desa, Kepala Otoritas Pantai obyek wisata Pantai Matahari Terbit, Pantai Bali Beach, dan Pantai Segara Ayu. Informan dalam tahap wawancara terstruktur atau structure interview, informan dalam tahap ini adalah pengelola parkir, pemilik usaha di seputaran desa wisata Sanur Kaja. Pengolahan dan analisis data yang di gunakan dalam penelitian ini adalah teknik analisis data deskriptif kualitatif di mana jenis data yang terbentuk informasi baik lisan maupun tulisan yang sifatnya bukan angka. Data di kelompokkan agar lebih mudah dalam menyaring mana data yang dibutuhkan dan mana yang tidak.

\section{Hasil dan Pembahasan}

Guna mewujudkan Desa Sanur Kaja sebagai Desa Wisata, pihak pengelola desa wisata di Desa Sanur Kaja telah menerapkan manajemen modern. Hal ini dilakukan sesuai dengan tuntutan jaman. Salah satu manajemen modern yang telah diterapkan pengelola wisata di Desa Sanur Kaja adalah dengan menerapkan manajemen pemasaran digital. Pemilihan strategi marketing dalam memasarkan dan mempromosikan objek-objek wisata di Desa Sanur Kaja sangatlah penting dalam mencapai tujan dan meningkatkan kunjungan wisatawan. Dalam hasil wawancara dengan sejumlah informan, ditemukan bahwa strategi pemasaran Desa Wisata Desa Sanur Kaja melalui e-commerce dengan menggunakan website dan media sosial guna meningkatkan kunjungan wisatawan ke destinasi wisata tersebut sudah terlealisasi dengan baik.

Adanya e-commerce dirasakan cukup efektif membantu dalam pemasaran pariwisata di Desa Sanur Kaja khususnya dalam segi promosi. Sebab promosi bisa dilakukan dengan cepat ke seluruh dunia tanpa terkendala jarak dan waktu. Biaya yang diperlukan juga bisa lebih murah. Pemasaran pariwisata di Desa Sanur Kaja dirasakan memang lebih efektif jika memanfaatkan e-commerce, baik melalui website maupun media sosial. Sebab promosi dan pemasaran e-commerce dianggap lebih menghemat waktu dan biaya. Wisatawan juga bisa lebih mudah mendapatkan akses informasi dan melakukan aktivitas terkait pariwisata misalnya memesan kamar hotel secara online

Pemasaran paket jasa atau produk pariwisata yang ditawarkan melalui e-commerce baik di website dan media sosial juga menunjukkan hasil yang berbeda jika dibandingkan dengan cara pemasaran tradisional lainnya misalnya promosi dengan brosur, door to door, iklan di media cetak atau elektronik dan yang lainnya. Keunggulan tersebut menyangkut biaya promosi dan pemasaran yang lebih murah, tingkat marjin atau keuntungan yang lebih 
tinggi, cakupan pasar yang lebih luas dan lain-lain. Lebih lanjut mengenai moda transportasi yang ada di Desa Sanur Kaja, diketahui bahwa transportasi di Desa Sanur Kaja selain ada transportasi umum seperti Metro Dewata juga ada transportasi online serta transportasi milik Desa Sanur Kaja.

Berdasarkan hasil penelitian diatas, maka untuk selanjutnya dilakukan pembahasan dengan mengacu pada hasil penelitian tersebut. Upaya-upaya yang dilakukan Desa Sanur Kaja dalam mengelola Desa Wisata berbasis manajemen modern diantaranya dilakukan melalui: 1) Pendekatan pasar, 2) Pendekatan Fisik, 3) Peningkatan Kapasitas Desa, 4) Jalur Transportasi, 5) Keamanan, dan 6) Manajemen Modern,

Pendekatan pasar. Pendekatan pasar yang dilakukan oleh Desa Sanur Kaja dalam mewujudkan Desa Sanur Kaja sebagai Desa Wisata adalah melalui tiga interaksi. Pertama melalui interaksi langsung, yaitu model model pengembangan didekati dengan cara bahwa desa mendapat manfaat tanpa interaksi langsung dengan wisatawan. Bentuk interaksi tidak langsung yang ada di Desa Sanur Kaja dalam menunjang desa wisata adalah dengan membuat buku keberadaan Desa Sanur Kaja. Dalam bukut tersebut memuat tentang topografi Desa Sanur Kaja, fasilitas-fasilitas umum, obyek wisata, kelembagaan desa, baik desa adat maupun desa dinas dan yang lainnya. Kedua, interaksi setengah langsung berupa bentuk-bentuk one day trip yang dilakukan oleh wisatawan, kegiatan-kegiatan meliputi makan dan berkegiatan bersama penduduk dan kemudian wisatawan dapat kembali ke tempat akomodasinya. Prinsip model tipe ini adalah bahwa wisatawan hanya singgah dan tidak tinggal bersama dengan penduduk. Interaksi setengah langsung yang dilakukan Desa Sanur Kaja dalam upaya menunjang desa wisata dalah dengan membuat tempat-tempat istirahat wisatawan seperti sekepat, tempat minum di pinggir pantai dan yang lainnya. Dan ketiga adalah interaksi langsung. Interkasi langsung berupa istirahat langsung dimungkinkan untuk tinggal/bermalam wisatawan seperti hotel. Desa Saur Kaja memiliki fasilitas akomodasi penginapan berupa hotel dan villa yang telah memadai, temuan penelitian ini sejalan dengan pendapat (Tenggara et al., 1981)

Pendekatan Fisik. Pendekatan fisik merupakan solusi yang umum dalam mengembangkan sebuah desa melalui sektor pariwisata dengan menggunakan standarstandar khusus dalam mengontrol perkembangan aktivitas konservasi. Sanur mengandalkan obyek pantai sebagai penunjang pariwisata. Salah satu obyek wisata yang ada Desa Sanur Kaja dadalah Pantai Matahari Terbit. Selain pantai juga ada Museum Le Mayeur.

Peningkatan kapasitas desa. Dalam mengembangkan desa wisata di Desa Sanur Kaja, pelibatan masyarakat menjadi prasyarat mutlak. Namun ketika hendak melibatkan masyarakat agar mau berperan serta dalam proses pengembangan desa wisata tidak bisa terjadi begitu saja. Karena setiap masyarakat memiliki karakteristiknya masing-masing. Setiap masyarakat memiliki potensi konflik dan faksi-faksi, yang ibarat jerami kering, bisa terbakar kapanpun pada saat angin meniup. Hambatan terbesar biasanya ada pada persoalan kapasitas dan pemahaman masyarakat tentang desa wisata. Karena melibatkan masyarakat menjadi prasyarat utama maka proses pemberian pemahaman dan peningkatan kapasitas sering memakan waktu lama. Target utama dalam peningktan kapasitas masyarakat dalam program desa wisata di Desa Sanur Kaja adalah pelibatan masyarakat desa adat.

Jalur transportasi. Guna mendukung terwujudnya Desa Sanur Kaja sebagai desa wisata, Desa Sanur Kaja telah menyediakan transportasi umum. Transormasi umum yang melayani transformasi di Desa Sanur Kaja adalah Metro Denpasar. Selain transformasi umum juga ada transfortasi online serta transfortasi yang dikelola oleh Desa Sanur Kaja. Sehingga untuk masalah transportasi di Desa Sanur Kaja untuk mendukung pariwisata sudah tidak ada masalah. 
Keamanan. Model keamanan yang diterapkan di Desa Sanur Kaja untuk menjaga keamanan wisata adalah partisipasi desa adat, desa dinas dan pihak kepolisian. Dari pihak kepolisian ada Babhinsa, dari pihak desa adat ada pecalan dan dari desa dinas ada Hansip. Satuan pengamanan ini terus berjaga selama 24 jam, secara bergantian. Upaya ini dilakukan agar wisatawan yang berkunjung ataupun menginap di Desa Sanur Kaja merasa aman dan nyaman. Selain itu Desa Sanur Kaja juga memiliki petugas yang untuk menjaga lingkungan dan kebersihan. Petugas ini terus menjaga lingkungan dan kebersihan lingkungan Desa Sanur Kaja.

Manajemen modern. Salah satu indikator pelaksanaan manajemen modern yang dilakukan oleh Desa Sanur Kaja sebagai desa wisata adalah dengan dimanfaatkannya teknologi informasi dalam melakukan aktivitas pariwisata. Pemanfaatan media teknologi informasi seperti internet dalam upaya mendukung desa wisata adalah pemanfaatan internet sebagai media promosi. Selain pengelola wisata, pelaku-pelaku wisata yang ada di Desa Sanur Kaja juga telah memanfaatkan internet sebagai media promosi. Temuan hasil penelitian tersebut sejalan dengan sejumlah temuan Hays, Page, \& Buhalis (2013) media sosial kini menjadi sarana baru pembentukan citra objek wisata karena media sosial memungkinkan untuk mencapai target konsumen wisatawan secara global dengan sumber daya yang minimal. Sementara hasil penelitian Sumiari dan Triandini (2013:62) menemukan bahwa dengan adanya e-commerce business to busineess dan business to customer ini, para wisatawan dan reseller atau distributor dapat lebih mudah untuk mengetahui informasi dari produk-produk yang ada di daerah wisata. Sementara menurut Leung dkk. 2013 (dalam Wijaya, 2016:58) mengatakan bahwa dalam industri pariwisata, media sosial memiliki peran dalam rantai suplai mulai dari suplier sampai dengan konsumen.

Dalam penelitian di Desa Sanur Kaja ini ditemukan bahwa memang banyak wisatawan yang mendapatkan informasi mengenai pariwisata di kawasan tersebut melalui internet baik dengan mengakses website ataupun media sosial. Hal tersebut juga menjadi prilaku hampir seluruh wisatawan sebelum memutuskan mengunjungi suatu objek wisata. Temuan hasil penelitian tersebut sesuai dengan ITB World Travel Trend Report tahun 2015/2016 mengungkapkan bahwa 30\% wisatawan internasional yang menggunakan internet mendapatkan informasi mengenai perjalanan wisata mereka melalui media sosial. Media Sosial adalah suatu grup aplikasi berbasis internet yang menggunkan ideologi dan tehnologi Web 2.0, dimana pengguna dapat membuat atau bertukar informasi pada aplikasi tersebut dan Social media memberdayakan masyarakat untuk menjadi penyebar informasi (Handika \& Darma, 2018). Berdasarkan hasil pengamatan dan wawancara dengan informan, media sosial yang paling banyak digunakan dalam memasarkan pariwisata di Desa Sanur Kaja adalah Facebook dan Instagram. Tentu pemilihan kedua jenis media sosial yang pengguna aktif dari seluruh dunia ini mempunyai alasan tersendiri. Media sosial seperti Facebook dan Instragram dianggap sebagai sarana promosi yang efektif karena selain jumlah penggunanya yang besar, wisatawan juga kerap menggunakan Facebook dan Instagram untuk mencari informasi maupun foto-foto mengenai suatu objek atau destinasi pariwisata.

Selain itu juga pelaku usaha hotel dan restoran di kawasan Desa Sanur Kaja secara rutin mengunggah foto-foto objek wisata atau akomodasi pariwisata di daerah Sanur dengan tampilan visual yang menarik dan kretif sehingga diharapkan mampu menggugah minat dan rasa penasaran wisatawan. Unggahan foto tersebut juga dilengkap caption atau deskripsi dan cerita singkat mengenai objek wisata dan akomodasi pariwisata tersebut. Pihak hotel dan restoran juga menyampaikan berbagai informasi menarik seputar jasa dan produk pariwisata mereka melalui media sosial Facebook dan Instagram serta memberikan berbagai penawaran menarik misalnya diskon. 
Media sosial memiliki peran dalam membantu wisatawan dalam memutuskan pilihan alternatif tujuan wisata dan pengambilan keputusan dalam pembelian paket wisata. Menurut Sparks and Browning (2011), peran media sosial ini dipengaruhi oleh "user generated content "dalam media sosial sehingga informasi yang diunggah dalam media sosial mampu membantu wisatawan untuk mengambil keputusan. Studi lain dari Fotis dkk. (2011) dan Sparks \& Browning (2011) menunjukkan bahwa awareness dari wisatawan akan daerah tujuan wisata dipengaruhi oleh informasi yang diunggah melalui media sosial. Kepercayaan wisatawan akan informasi dalam media sosial memberikan pengaruh terhadap pengambilan keputusan dan keputusan untuk membeli produk selama proses berwisata berlangsung. Dengan demikian media sosial merupakan tempat dimana wisatawan berbagi pengalaman setelah melakukan perjalanan wisata.

Marketing mix atau bauran pemasaran adalah serangkaian element atau variabel pemasaran yang dikombinasikan atau dibaurkan oleh pemasar dalam upaya menciptakan, menawarkan, mengkomunikasikan atau mengirimkan produk atau jasa kepada konsumen atau pelanggan. Elemen bauran pemasaran atau (marketing mix) tersebut meliputi 7P yakni: place (tempat), product (produk), price (harga), promotion (promosi), people (orang), process (proses), dan physical evidence (bukti fisik). Menurut Chaffey dan Chadwick (2016:251) kehadiran internet berserta teknologi dan media digital menyediakan berbagai kesempatan baru kepada para pemasar seperti: memvariasikan aplikasi marketing mix, mengembankan jalur baru untuk mengirimkan keunggulan bersaing, mencipatakan posisi pasar baru, membangun hubungan dan pelayanan yang lebih baik untuk meningkatkan cara-cara inovatif, menghilangkan hambatan ruang dan waktu serta menawarkan akses yang berkelanjutan dan instan terhadap produk dan jasa

Kehadiran internet melahirkan konsep dan praktik digital marketing yang salah satu bentuknya adalah e-commerce baik dengan media website maupun media sosial. Menurut Chadwick (2016:251) kehadiran internet berserta teknologi dan media digital mempengaruhi seluruh aspek marketing mix tradisional. Product: adanya kesempatan memodifikasi produk inti atau perluasan produk untuk lingkungan digital. Price: adanya model dan strategi penetapan harga yang baru. Place: memerhatikan implikasi saluran distribusi untuk digital marketing. Promotion: mengeksplorasi teknik promosi lebih lanjut dengan bantuan teknologi dan media digital. People, process \& physical evidence: fokus pada bagaimana ketiga elemen ini berhubungan dengan manajemen hubungan pelanggan (customer relationship management) dan mengelola kehadiran organisasi secara digital

Produk merupakan elemen dari marketing mix yang menyangkut upaya pencarian dan pemenuhan kebutuhan konsumen kemudian mengembangkan produk yang sesuai dan memadai. Menurut Chadwick (2016:251) implikasi internet terhadap produk dalam digital marketing yakni: pilihan untuk memvariasikan produk inti (core product), pilihan untuk menawarkan produk digital, pilihan untuk mengganti extended product, melakukan riset secara online, adanya percepatan pembangunan produk baru, adanya percepatan difusi produk.

Dari sisi place (tempat), tentu para pelaku usaha pariwisata di Desa Sanur Kaja ketika memasarkan pemasaran pariwisata Desa Sanur Kaja secara online melalui ecommerce dengan menggunakan website dan media sosial, produk dan jasa pariwisata ditawarkan secara online. Informasi produk dan jasa pariwisata dikemas sedemikian rupa baik dengan teks, gambar atau foto maupun video lalu ditampilkan di website maupun media sosial sehingga menarik awareness dan minat wisatawan. Place (tempat) adalah elemen maketing mix yang mengacu pada bagaiman produk didistribusikan kepada konsumen atau pelanggan. Menurut Chadwick (2016:277) implikasi internet terhadap place (tempat) meliputi tempat pembelian, struktur saluran distribusi baru, konflik saluran distribusi dan organisasi virtual. Sedangkan dari sisi price (harga), para pelaku usaha pariwisata di Desa Sanur Kaja 
ketika memasarkan pemasaran pariwisata Sanur secara online melalui e-commerce dengan menggunakan website dan media sosial tentu menggunakan strategi penetapan harga (pricing) yang berbeda dibandingnkan pemasaran offline atau konvensional.

Price (harga) adalah elemen marketing mix yang merujuk pada kebijakan penepatan harga perusahaan terhadap produk atau jasanya. Menurut Chadwick (2016:268) ilmplikasi internet terhadap harga yakni: Meningkatkan transparansi harga dan impilikasinya terhadap penetapan harga yang berbeda, menurunkan tekanan harga termasuk komoditisasi, pendekatan baru dalam penetapan harga temasuk dynamic pricing, pricing testing dan auctions, dan alternatif struktur atau kebijakan penetapan harga.

Untuk aspek promotion (promosi), para pelaku usaha pariwisata di Desa Sanur Kaja ketika memasarkan pemasaran pariwisata Desa Sanur Kaja secara online menganggap website dan media sosial seperti Facebook dan Instragram dianggap sebagai sarana promosi yang efektif karena selain jumlah penggunanya yang besar, wisatawan juga kerap menggunakan Facebook dan Instagram untuk mencari informasi maupun foto-foto mengenai suatu objek atau destinasi pariwisata. Karenanya cara promosi dilakukan dengan mengunggah foto-foto terkait objek wisata, akomodasi pariwisata serta jasa maupun produk pariwisata lainnya yang mereka tawarkan di Desa Sanur Kaja dengan tampilan visual dan desain yang menarik. Promosi merupakan bagian dari elemen marketing mix dimana produk atau jasa dikomunikasikan kepada konsumen dan pelanggan dengan berbagai cara dan media komunikasi. Menurut Chadwick (2016:284) implikasi internet terhadap promosi yakni: Adanya cara baru dalam mengaplikasikan setiap elemen bauran promosi atau komunikasi seperti periklanan, promosi penjualan, public relation, direct marketing, dll. Dapat mengindetifikasi dan menilai bagaimanai internet digunakan oleh konsumen atau pelanggan pada tingkat proses pemberlian yang berbeda. Menggunakan sarana promosi untuk membantu mengelola berbagai tingkatan manajemen hubungan pelanggan yang berbedabeda.

Sementara Vinaya (2016:620-621) dalam hasil penelitiannya menemukan bahwa memang strategi promosi pariwisata secara online harus disesuikan dengan profil wisman Belanda dan media massa yang banyak digunakan oleh mereka. Media tradisional (cetak, penayangan) maupun media baru (sosial media) harus digunakan bersama-sama, terlebih wisman Belanda sangat mempercayai sumber informasi dari internet sebagai referensi liburan mereka. Informasi word-of-mouth via sosial media dan juga endorser keturunan Belanda, walau tidak formal namun diharapkan bisa menaikkan jumlah wisatawan. Implikasi media promosi POSE yang digunakan oleh Kementrian Pariwisata (Kemenpar) dapat terukur. Pengukuran melalui exposure atau tingkat jangkauan wisman, tingkat pemahaman wisman atas informasi yang diberikan sehingga terbujuk untuk datang ke Indonesia, dan tingkat efek penjualan. Jelas untuk Kemenpar bukanlah penjualan namun tingkat jumlah kunjungan wisman Belanda. Hasil penelitian Atiko dkk. (2016:9) juga menemukan bahwa Divisi Pemasaran Kementrian Pariwisata (Kemenpar) juga aktif menggunakan media sosial salah satunya instagram sebagai media mempromosikan pariwisata di Indonesia. Strategi promosi yang dilakukan oleh divisi Pemasaran Kementrian Pariwisata dalam penggunaan akun Instagram @indtravel sebagai media promosi pariwisata Indonesia adalah dengan melakukan beberapa tahapan yaitu: penciptaan konten, penentuan platform, membuat rencana program, implementasi program, monitoring, dan evaluasi.

Temuan serupa ditemukan dalam penelitian Libriyanto (2107:17) menemukan bahwa promosi yang dilakukan oleh pengelola wisata Bintang Nglambor Snorkeling yaitu dengan menyebarkan informasi tentang potensi wisata Pantai Nglambor melalui media sosial Instagram. Pada elemen process (proses), pemasaran pariwisata Desa Sanur Kaja secara online melalui e-commerce dengan menggunakan website dan media sosial tentu lebih mudah dan lebih sederhana serta lebih cepat terealisasi dibandingkan dengan pemasaran 
konvensional atau offline. Terakhir untuk aspek physical evidence (bukti fisik), tentu tampilan dan design website serta media sosial baik Instagram maupun Facebook memegang peran krusial. Jika tampilan dan design website serta media sosial baik Instagram maupun Facebook dikemas dengan menarik dan mudah diakses melalui berbagai perangkat baik komputer, smartphone maupun tablet, maka tentu akan mempermudah wisatawan. Selain itu kualitas dan tampilan foto maupun video yang diunggah baik website maupun media sosial juga dibuat lebih menarik dengan sudut pandang yang berbeda dan baru agar mampu menampilkan keindahan objek wisata Desa Sanur Kaja secara lebih natural dan unik. Hasil penelitian Pradiatiningtyas (2014:86-87) menyimpulkan bahwa bauran pemasaran jasa dan positioning memiliki peran terhadap pemasaran online pariwisata di Indonesia. Dengan perangkat teknologi dan jaringan sinergi ketiga hal tersebut akan dapat menjangkau masyarakat luas di Indonesia bahkan dunia dengan informasi yang lengkap sehingga dapat memenuhi kebutuhan konsumen akan informasi yang dibutuhkan. Elemen pembentuk pemasaran pariwisata online adalah dengan e-tourism, bauran pemasaran jasa, dan positioning. Dimana hal tersebut merupakan tahapan awal pelaku usaha wisata mengidentifikasi hal-hal krusial agar pemasaran online akan usaha wisatanya terbentuk dengan baik.

Pemasaran online pariwisata dirasa lengkap apabila mampu menghantarkan seluruh informasi yang dibutuhkan berserta fasilitas pendukung, penunjuk arah, dan hal-hal terkait. Pemasaran online yang baik dan terintegrasi dapat mendukung tingkat kunjungan wisata sehingga mampu menaikkan pendapatan daerah. Efektifitas suatu website, media sosial, dan bentuk pemasaran online ditentukan juga oleh menu atau informasi yang disajikan oleh operatornya. Dengan melakukan pemasaran pariwisata Desa Sanur Kaja secara online melalui e-commerce dengan menggunakan website dan media sosial para pelaku usaha pariwisata di Desa Sanur Kaja banyak mendapatkan berbagai manfaat sebagaimana telah disebutkan dalam hasil penelitian di atas. Mereka juga merasa optimis dan yakin bisa bersaing dan menjadi semakin kompetitif di tengah ketatnya persaingan industri pariwisata di Bali dan pariwisata global.

\section{Simpulan Dan Saran}

Berdasarkan temuan penelitian dapat disimpulkan seperti berikut: Melakukan pendekatan pasar melalui interaksi yaitu Desa Sanur Kaja dalam menunjang desa wisata adalah dengan membuat buku keberadaan Desa Sanur Kaja. Keberikutnya adalah dengan interaksi setengah langsung berupa bentuk-bentuk one day trip yang dilakukan oleh wisatawan, kegiatan-kegiatan meliputi makan dan berkegiatan bersama penduduk dan kemudian wisatawan dapat kembali ke tempat akomodasinya. Terakhir adalah dengan interaksi langsung. Interkasi langsung berupa istirahat langsung dimungkinkan untuk tinggal/bermalam wisatawan seperti hotel. Desa Saur Kaja memiliki fasilitas akomodasi penginapan berupa hotel dan villa yang telah memadai. Melalui Pendekatan fisik yaitu mengembangkan sebuah desa melalui sektor pariwisata dengan menggunakan standarstandar khusus dalam mengontrol perkembangan aktivitas konservasi. Sanur mengandalkan obyek pantai sebagai penunjang pariwisata. Salah satu obyek wisata yang ada Desa Sanur Kaja dadalah Pantai Matahari Terbit. Selain pantai juga ada Museum Le Mayeur. Melalui peningkatan kapasitas desa, yaitu pelibatan masyarakat menjadi prasyarat mutlak. Namun ketika hendak melibatkan masyarakat agar mau berperan serta dalam proses pengembangan desa wisata tidak bisa terjadi begitu saja. Karena setiap masyarakat memiliki karakteristiknya masing-masing. Setiap masyarakat memiliki potensi konflik dan faksi-faksi, yang ibarat jerami kering, bisa terbakar kapan pun pada saat angin meniup. Hambatan terbesar biasanya ada pada persoalan kapasitas dan pemahaman masyarakat tentang desa wisata. Melalui penyediaan sarana transportasi, baik transportasi umum maupun 
transportasi online. Keamanan yang memadai, yaitu melalui model keamanan kolaborsi antara kepolisian, TNI, desa adat dan desa dinas. Melakukan penerapan manajemen modern, yaitu dengan memanfaatkan teknologi informasi dalam melakukan aktivitas pariwisata. Pemanfaatan media teknologi informasi seperti internet dalam upaya mendukung desa wisata adalah pemanfaatan internet sebagai media promosi. Selain pengelola wisata, pelaku-pelaku wisata yang ada di Desa Sanur Kaja juga telah memanfaatkan internet sebagai media promosi.

\section{Daftar Pustaka}

Adnyana, R., \& Darma, G. S. (2015). Strategi Marketing Mix, Yield Management, Customer Satifaction and Occupany Rate. Jurnal Manajemen Dan Bisnis, 12(1), 98-121. http://dx.doi.org/10.38043/jmb.v12i1.288

Arianti, N. L. N., Darma, G. S., \& Mahyuni, L. P. (2019). Menakar Keraguan Penggunaan QR Code Dalam Transaksi Bisnis. Jurnal Manajemen Bisnis, 16(2), 67. https://doi.org/10.38043/jmb.v16i2.2041

Asri, A. A. S. M. A. N., \& Darma, G. S. (2020). Revealing the digital leadership spurs in 4.0 industrial revolution. International Journal of Business, Economics \& Management, 3(1), 93-100. https://doi.org/10.31295/ijbem.v3n1.135

Bali, I. N. A. P., \& Darma, G. S. (2019). Menguji Kesiapan Pengelolaan Desa Berbasis Manajemen Modern Guna Menghadapi Era Revolusi Industri 4.0. Jurnal Manajemen Bisnis, 16(2), 1-13. https://doi.org/10.38043/jmb.v16i2.2037

Bastian, I., Winardi, R. D., \& Fatmawati, D. (2018). Metoda Wawancara. https://www.researchgate.net/publication/331556677_Metoda_Wawancara

Berdesa. (2015). Merumuskan Strategi Pengembangan Desa Wisata. Berdesa.Com. http://www.berdesa.com/merumuskan-strategi-pengembangan-desa-wisata/, diakses pada tanggal 7 Mei 2020.

Berdesa. (2017). Desa Harus Memenuhi Syarat Ini Untuk Jadi Desa Wisata. Berdesa.Com. https://www.berdesa.com/desa-harus-memenuhi-syarat-jadi-desa-wisata/, diakses pada tanggal 8 Mei 2020.

Darma, G. S. (2004). The Impact of Information Technology Investment on the Hospitality Industry. Seminar Nasional Aplikasi Teknologi Informasi 2004. https://journal.uii.ac.id/Snati/article/view/1783/1562

Delfiliana, F., \& Dewi, D. I. K. (2016). Kajian Tingkat Kesiapan Masyarakat Kawasan Tambak Lorok Terhadap Pengembangan Kampung Wisata Bahari. RUANG, 2(3), 216-

Dewi, M. V. K., \& Darma, G. S. (2019). The Role of Marketing \&amp; Competitive Intelligence In Industrial Revolution 4.0. Jurnal Manajemen Bisnis, 16(1), 1. https://doi.org/10.38043/jmb.v16i1.2014

Handika, M. R., \& Darma, G. S. (2019). Strategi Pemasaran Bisnis Kuliner Menggunakan Influencer Melalui Media Sosial Instagram. Jurnal Manajemen Bisnis, 15(2). https://doi.org/10.38043/jmb.v15i2.601

Ensiklo. Konsep (2019). Pengembangan Desa Wisata. http://ensiklo.com/2019/10/21/pengertian-desa-wisata/, diakses pada tanggal 12 Mei 2020.

Manteiro, M. C. . (2016). Model Pengembangan Desa Wisata Berbasis Kearifan Lokal Sebagai Strategi Pengentasan Kemiskinan Di Kabupaten Rote Ndao Nusa Tenggara 
Timur. Bisman Jurnal Bisnis Dan Manajemen, 2(2), 93-101. https://doi.org/https://doi.org/10.32511/bisman.v2i2.56

Nurazizah, G. R., \& Darsiharjo, D. (2018). Kesiapan Masyarakat Desa Wisata Di Kampung Seni \& Budaya Jelekong Kabupaten Bandung. Jurnal Geografi Gea, 18(2), 103. https://doi.org/10.17509/gea.v18i2.13524

Nuryanti, W. (1993). Concept, Perspective and Challenges, makalah bagian dari Laporan Konferensi Internasional mengenai Pariwisata Budaya. Gadjah Mada University Press. Jogjakarta, 2-3.

Pratama, F. G., \& Kurnia, G. (2018). Strategi Pengembangan Desa Wisata Berbasis Masyarakat (Studi Kasus: Desa Lebakmuncang, Kecamatan Ciwidey, Kabupaten Bandung). Jurnal IImiah Mahasiswa AGROINFO GALUH, 5(1), 1014-1028. https://doi.org/10.25157/jimag.v5i1.1572

Sedarmayanti. (2012). Good Governance "Kepemerintahan Yang Baik" \& Good Corporate Governance "Tata Kelola Perusahaan Yang Baik" Bagian Ketiga Edisi Revisi (B. C. M. Maju (ed.)). Bandung CV.Mandar Maju.

Tenggara, N., UNDP, Organization, W. T., \& Indonesia. (1981). Indonesia: Review and Updating of the 1981 Tourism Development Plan for Nusa Tenggara: Final Report. Diambil dari https://digitallibrary.un.org/record/137465? In=en.

Tyas, N. W., \& Damayanti, M. (2018). Potensi Pengembangan Desa Kliwonan sebagai Desa Wisata Batik di Kabupaten Sragen. Journal of Regional and Rural Development Planning, 2(1), 74. https://doi.org/10.29244/jp2wd.2018.2.1.74-89

Utomo, I. G. W., \& Darma, G. S. (2020). Measuring optimization of digital military programs: an innovation of information and communication systems in industrial digitalization 4.0. International Research Journal of Engineering, IT \& Scientific Research, 6(2), 39-46. https://doi.org/10.21744/irjeis.v6n2.862

Widana, I. W., \& Darma, G. S. (2018). Branding Denpasar Smart City Guna Meningkatkan Kunjungan Wisatawan. Jurnal Manajemen Dan Bisnis, 15(1), 176-199. https://doi.org/10.38043/jmb.v15i1.370

Widani, N. M., Abiyasa, A. P., \& Darma, G. S. (2019). Menguji Ketajaman Implementasi ECommerce Dalam Penjualan Kamar Hotel di Bali. Jurnal Manajemen Bisnis, 16(2), 79_ 98. https://doi.org/10.38043/jmb.v16i2.2042

Widiatmika, P. H., \& Darma, G. S. (2018). Good Corporate Governance, Job Motivation, Organization Culture Which Impact Company Financial Performance. Jurnal Manajemen Dan Bisnis, 82-99. https://doi.org/http://dx.doi.org/10.38043/jmb.v15i3.608 